\title{
CLARO QUE VENGO* A TU FIESTA: LA ENSEÑANZA DE LOS VERBOS DEÍCTICOS IR/VENIR Y LLEVAR/ TRAER A ESTUDIANTES ANGLOPARLANTES
}

Daniel Chui

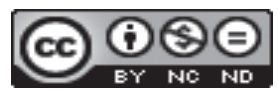

Esta obra está bajo una licencia Creative Commons 



\title{
CLARO QUE VENGO* A TU FIESTA: LA ENSEÑANZA DE LOS VERBOS DEÍCTICOS IR/VENIR Y LLEVAR/ TRAER A ESTUDIANTES ANGLOPARLANTES
}

\author{
CLARO QUE VENGO* A TU FIESTA: TEACHING THE DEICTIC \\ VERBS IR/VENIR AND LLEVAR/TRAER TO ENGLISH L1 SPEAKERS
}

\begin{abstract}
RESUMEN
El presente estudio tiene como objetivo determinar si el enfoque pedagógico conocido como Processing Instruction (PI) (VanPatten 1996, 2002) es tan eficaz como el enfoque Meaning-Based Output Instruction (MOI) (Farley, 2001b) en la enseñanza de los patrones de uso de los verbos deícticos en español a hablantes nativos del inglés. Los verbos en cuestión son ir, venir, llevar y traer. Este trabajo pretende investigar en primer lugar si los hablantes nativos del inglés pueden aprender el sistema más restrictivo del castellano (Gathercole, 1978; Lewandowski, 2007). En el estudio, tres grupos fueron comparados: un grupo de control, uno de PI y otro de MOI. Cada grupo hizo una pre y post-prueba de interpretación y de producción. Los dos grupos de tratamiento recibieron instrucción entre pre y postprueba. La participación en cualquiera de los dos grupos de tratamiento fue positivamente correlacionada con un rendimiento superior en la prueba de interpretación, pero no en las pruebas de producción. En general, los resultados sugieren que, a pesar de que los participantes se beneficiaron de la instrucción en el experimento de interpretación, los estudiantes en el tercer trimestre del primer año de español no son capaces todavía de producir los verbos deícticos de manera diferente a su lengua materna. Palabras clave: verbos deícticos, Processing Instruction, Meaning Based Output Instruction, español como segunda lengua, ir y venir.
\end{abstract}

\begin{abstract}
The present study compares two instructional methods-processing instruction (PI) (VanPatten 1996, 2002) and meaning-based output instruction (MOI) (Farley, 2001b) -in the teaching of Spanish deictic verbs ir 'to go', venir 'to come', llevar 'to take', and traer 'to bring' to English L1 speakers. The grammatical topic was chosen because it represents a contrastive difference between Spanish and English verb choice (Gathercole, 1978; Lewandowski, 2007), in which the natural processing tendencies of English speakers may lead to suboptimal learning outcomes. The study compared the learning outcomes of three groups of first-year Spanish students: a control group, an MOI group, and a PI group. All groups participated in pre and post-tests in interpretation and production of the deictic verbs, with the treatment groups receiving instruction between the tests. The results showed that participation in either treatment group was positively correlated with higher performance in the interpretation, but not the production tasks. Students in their third quarter of firstyear Spanish are developmentally prepared to benefit from instruction on the verbs venir, ir, traer and llevar with regards to interpreting input. However, they do not appear to be developmentally ready to apply this instruction to the actual production of these verbs. Key words: verbal deixis, Processing Instruction, Meaning Based Output Instruction, Spanish second language, come and go.
\end{abstract}

M.A. Daniel Chui. Universidad de California, Santa Bárbara. Departamento de Español y Portugués. Estados Unidos.

Correo electrónico: dchui@umail.ucsb.edu

Recepción: 29- 04- 15

Aceptación: 11- 09- 15 


\section{Introduction}

While L2 Spanish classrooms and textbooks devote a great deal of attention to subjects like tense and mood selection (Collentine, 2010), an important area of difference between Spanish and English has largely gone ignored by Spanish-language curricula: the deictic verbs. The present study is both exploratory -in that data will be gathered on native English speakers' production of the deictic verbs ir 'to go', venir 'to come', llevar 'to take' and traer 'to bring' -and experimental in that meaning-based output instruction (Farley, 2001a \& b; Morgan-Short \& Bowden, 2006) will be compared with Processing Instruction (VanPatten, 1996, 2002). The second section compares the usage of deictic verbs in Spanish and English. The third section provides a literature review of PI and posits how PI can be used to raise the communicative value of the coming/going and bringing/taking verbs in second-language learners of Spanish. The fourth and fifth sections outline the research questions and present the method, followed by the results, discussion and conclusion.

\section{Deictic Verbs in English \& Spanish}

Shum et ál. (1989) examined the use of the deictic verbs venir, traer, ir and llevar among Spanish-speaking children in Spain. These authors defined deictic verbs as "those verbs that refer to movement and imply reference to the direction of this movement, its objectives, and its cause" (p. 50; translated by author from original text in Spanish). The authors argue that in Spanish, venir and traer generally involve movement towards the speaker, whereas ir and llevar involve movement away from the speaker: "With respect to verbal deixis, the directionality corresponding with the action was taken into consideration: that is, if this directionality was oriented towards the speaker (venir, traer) or away from the speaker (ir, llevar)" (p. 51; present author's translation).

The deictic rules of Spanish coming and going verbs present unique challenges to English speakers, since in English the verbs come and bring can both refer to movement away from the speaker's present location, towards the location of the person they are talking to (Lewandowski, 2007).

In this section, I take as a starting point Lewandowski (2007) analysis of deictic verbs in Spanish and English. For the purposes of the present experiment, I will limit the analysis to the prototypical cases involving the use of come and go involving movement either towards the speaker or towards the hearer or addressee (Lewandowski, 2007, p. 21). While Lewandowski work focuses primarily on the verbs come and go, the present project expands the parameters to include the related concept of bringing and taking (Shum et ál., 1989).

\subsection{Movement towards addressee and movement towards speakers}

Lewandowski (2007, p. 21) provides an analysis of the Spanish deictic verbs based on the framework established in Fillmore's seminal Santa Cruz Lectures (1975) on deictic verbs in English. The author examines movement towards and away from the speaker in three separate contexts: movement at coding time, movement at reference time, and movement towards the speaker/hearer's home-base. The present experiment only examines movement at coding time, either towards the speaker or towards the person the speaker is talking to in that moment, the addressee. Movement at coding time refers to movement that either takes place at the time of the enunciation, or at some other time which makes reference to the location of the speaker or hearer at the time of the utterance (Lewandowski, 2007, p. 22). 
(1) Él viene ahora.

He's coming over now.

(2) Mi abuela vino aquí ayer.

My grandmother came here yesterday.

(1) shows an example of movement oriented towards the speaker at the moment of enunciation - that is, at coding time. (2) is a second example of movement that references the speaker's location at coding time: while the action takes place in the past, the definition of "here" is defined by the speaker's location at the time of the enunciation.

\subsubsection{Movement Towards the Location of Speaker at Coding Time}

It is expected that L1 English speakers will face little difficulty choosing the appropriate deictic verb in Spanish when the movement refers to movement towards the speaker's location at coding time. In both English and Spanish, movement towards the speaker at coding time can only be expressed by the coming verb (Lewandowski, 2007, p. 21):

(6) Ven/*ve aquí

Come/*go here

(7) Mi abuelo vendrá/*va aquí mañana

My grandfather will come/*go here tomorrow

Both (6) and (7) show the permissibility of come/venir and the ungrammaticality of go/ ir in both English and Spanish, when the movement refers to movement towards the speaker's location at coding time. Following Shum et al. (1989), who affirm that the bringing verb traer involves movement towards the speaker's location, we can derive the following two examples:

(8) Si vienes a mi fiesta, por favor, trae/lleva* algo.

If you're coming to my party, please bring/take* something.

(9) Cuando me vengas a visitar, que los niños traigan/lleven* sus paraguas, que va a llover. When you come visit me, have the kids bring/take*1 their umbrellas because it's going to rain.

In (8), the usage of the verb traer is obligatory due to the choice of venir in the matrix clause. The speaker is either presently at the location where the party will take place, or the party is taking place at a home-base location strongly associated with the speaker. Similarly, in (9) the choice of the verb traer instead of llevar is obligatory, as the destination of the movement is the speaker's location at the time of the enunciation. A problem arises, which we shall examine in greater depth in the following section: the choice of the bring verb in English does not exclusively communicate movement towards the speaker's location, as is the case in Spanish. It can also capture movement away from the speaker's location, towards the addressee, at coding time.

\subsubsection{Movement Away from the Location of Speaker at Coding Time}

According to Lewandowski (2007, p. 26), “in English movement toward the addressee's location at coding and reference time... can be described with both come and go". He notes, however, that the situation is "quite different in Spanish". 
(10) Ya voy/*vengo a tu casa.

I'm going/coming over to your place.

(11) ¿Adónde vas? ¿Puedo ir/venir* contigo?

Where are you going? Can I go/come with you?

(10) and (11) show that Spanish does not permit the use of the coming verb when the movement expresses a movement away from the speaker's location at coding time. In this case, the movement expressed is towards a location associated with the addressee, such as the addressee's home in (10) and the addressee's intended destination in (11). In contrast with Spanish, we note in (10) and (11) that English permits both come and go to express movement away from the speaker's location, towards an addressee. A similar case arises with the verbs take and bring (Shum et ál., 1989).

(12) Llego a tu casa en diez minutos. ¿Quieres que lleve/traiga* algo?

I'll be at your house in ten minutes. Do you want me to take*/bring something?

(13) Cuando te visite el viernes, traeré*/llevaré a mi hermano.

When I visit you on Friday, I'll bring/take* my brother.

In both (12) and (13) the movement is towards the addressee and away from the speaker's location at coding time. The examples above illustrate that for the bringing and taking verbs used to express movement towards an addressee, what is grammatical in English is not permissible in Spanish, and vice versa. Transporting an object from the speaker's current location towards an addressee's location falls within the realm of the verb llevar and not traer in Spanish - that is, taking rather than bringing. Conversely, the same action in English requires the bring verb, and the take verb would not be grammatical in this context.

Examples (10-13) demonstrate that the English L1 speakers cannot rely on their intuition when the movement is oriented towards the addressee's location at coding time. In the case of coming and going, Spanish forbids the use of venir to express movement away from the speaker's location at coding time. Similarly, Spanish forbids the use of traer to express conveyance of an object away from the speaker's location at coding time (Lewandowski, 2007, p. 26). The present study will shed light on the extent to which native speakers of English apply the verbal-deictic rules predicted in (6)-(13) in their interlanguage. It is expected that English speakers will overgeneralize the use of the verbs venir and llevar in cases that express movement towards the addressee at coding time.

\section{Input Processing and Processing Instruction}

Most of the literature on input processing and processing instruction (PI) (VanPatten \& Cadierno 1993; VanPatten, 1996, 2000) has drawn a sharp divide between input-oriented and output-oriented approaches to L2 instruction. Traditional instruction (TI) is production oriented: "after the rules are explained, the instructor guides students to produce the grammatical form practiced, progressing from controlled mechanical drills, to meaningful practices, and to open-ended communicative practices" (Cheng, 2002, p. 309). This output-oriented approach, however, has been deemed problematic by authors who identify input as the driving factor of language acquisition. Under VanPatten \& Cadierno's Model of Second Language Acquisition and Use (1993), for example, output is considered a product of acquisition, rather than an agent of it (Collentine, 1998, p. 578). 
(14) A Model of Second Language Acquisition and Use (VanPatten \& Cadierno, 1993) Input $\rightarrow$ Intake $\rightarrow$ Developing System $\rightarrow$ Output

Processing Instruction, a pedagogical approach first developed in VanPatten \& Cadierno (1993), draws upon a specific set of input processing strategies that L2 learners rely upon when interpreting the input. While these strategies may generally assist learners in processing a foreign language, VanPatten \& Cadierno (1993) show that the overgeneralization of these strategies in the acquisition of certain grammatical forms can lead to suboptimal results. For example, VanPatten \& Cadierno (1993) examine the effect of PI on L1 English L2 Spanish speakers' performance in the interpretation and production of Spanish OVS phrases ("lo ve María"/María sees him). The first-noun principle (VanPatten, 2002, p. 758) is one input processing strategy that predicts that speakers of a foreign language tend to identify the first noun in a sentence as the subject. Thus, L1 English speakers will tend to misinterpret OVS phrases as SVO phrases. Learners may interpret a sentence like "lo ve María" as "he sees María" rather than the correct "María sees him".

Providing processing instruction on the proper interpretation of OVS phrases in Spanish involves two principle components: 1) explicit information about the target form and the unfavorable processing strategy (in this case the first-noun principle) and 2) structured input activities, which involve input that has been altered or manipulated in such a way so that learners "become dependent on form and structure to get meaning... so that learners have a better chance of attending to it (i.e., learners are pulled away from their natural processing tendencies toward more optimal tendencies)" (VanPatten, 2002, p. 765). In other words, the main goal of PI is to push learners to "abandon their inefficient processing strategies for more optimal ones so that better form-meaning connections are made" (Wong cited by Benati, 2005, p. 69).

VanPatten \& Cadierno (1993) found that PI outperformed TI in input-oriented interpretation tasks and performed as well as TI in output-oriented sentence-level completion tasks. This study in turn motivated many other studies in the following decade, in which PI was compared to TI and control groups. The results of these studies, which are succinctly summarized in Morgan-Short \& Bowden (2006, p. 34), suggest that PI generally outperforms both control groups and TI in both output-oriented and input-oriented tasks. The present study therefore recognizes the importance of educating students with a combination of explicit information and processing strategies. Both treatment groups maintained fidelity to this aspect of PI, following previous studies (Farley, 2001a \& 2001b; Benati, 2005; Morgan-Short $\&$ Bowden, 2006). The PI and MOI treatment groups only differed in the mode of practice, whether input-based in the case of PI or output-based in the case of MOI.

\subsection{Meaning-Based Output Instruction}

Meaning-based output instruction is defined by Morgan-Short \& Bowden (2006, p. 42) as an instructional method that closely resembles PI, containing grammatical explanations paired with processing strategies, but that differs in the mode of practice. While students who receive PI process input in structured input activities without producing the target form, students who receive MOI instruction practice the grammatical structure through meaningful sentence-completion tasks. Both PI and MOI provide explicit feedback for students at the end of each practice activity.

Farley (2001a) compared MOI to PI and found that the PI group outperformed the MOI group in the interpretation task, but that there was no difference between the groups in 
the production task. These results resembled those of VanPatten \& Cadierno (1993). In contrast, Farley (2001b) found no differences between PI and MOI on either the interpretation or output tasks. Farley (2001b) suggested that these differences may have arisen due to two factors, which are discussed in Morgan-Short \& Bowden (2006, p. 42): 1) the first experiment had fewer test items, thus students in the second experiment may have received more "focused input" at the time of receiving corrections than students in the first group and 2) the participants in the second study (2001b) belonged to a more intensive track of study. Morgan-Short \& Bowden (2006, p. 42) note, however, that "there is no underlying justification for why these factors would have affected the treatment groups differentially... they fail to explain why the MOI group would have benefited more from these factors than the PI group".

Benati (2005) compared TI, PI, and MOI in the teaching of the English simple past tense and found that PI outperformed both TI and MOI on the interpretation task and all groups performed equally well on the production task. Finally, Morgan-Short \& Bowden (2006) examined OVS word-order in Spanish and compared MOI to PI. The authors found that both groups improved in both interpretation and production tasks when comparing immediate and delayed posttests with pretests. However, only the MOI group significantly outperformed the control group in the production task.

The present study hopes to shed light upon the relative value of pairing explicit instruction and input processing strategies (VanPatten \& Cadierno, 1993) with differing modes of practice.

\subsection{Processing and Production Strategies for Ir/Venir and Llevar/Traer}

Verbal deixis presents a unique challenge to L2 learners of Spanish whose mother tongue is English. As explained in Section 2, the natural processing tendency for L1 English speakers permits the use of the verbs come and bring to express both movement away from and towards the speaker. In contrast, Spanish generally forbids the use of the venir and traer verbs in the case of movement away from the speaker's location at coding time. The present study adopts aspects of processing instruction while noting that the difficulties associated with verbal deixis in L2 Spanish are most likely to arise in production, rather than in the input. Nevertheless, it is hypothesized that providing structured input designed to elucidate faulty processing strategies in the L2 will help students to notice the more limited deictic dimensions of venir and traer in Spanish. The following examples illustrate cases in which a faulty processing strategy could lead to a misinterpretation of the input.

(15) Ahora vengo.

L1 Spanish speaker means: I'll be right back

L2 Spanish learner interprets: I'm coming now

In (15), the rules of verbal deixis in Spanish render the semantic meaning of the phrase "ahora vengo" unambiguous, even lacking additional context. Since venir may only be used to express movement towards the speaker's current location, the sole interpretation of "ahora vengo" is that the speaker will realize a movement away from their present location and then return to the same location. This meaning is captured by the gloss, "I'll be right back". However, an L1 English/L2 Spanish speaker is unlikely to extract the same meaning absent additional context, since English would permit the interpretation that the speaker of "ahora vengo" intends to move towards an addressee who is not present at the speaker's location. The above example demonstrates that utterances that unambiguously denote movement towards the 
speaker's location may be misinterpreted by speakers whose mother tongue possesses a more permissive verbal-deictic system.

(16) Que los niños traigan sus paraguas, que va a llover.

L1 Spanish speaker means: Have the children bring (to my location) their umbrellas, because it's going to rain.

L2 Spanish hearer interprets: Have the children bring (to my location or to another location) their umbrellas, because it's going to rain.

In (16), the choice of the verb traer by the native Spanish speaker unambiguously communicates that the destination of the movement is the speaker's location. The English hearer, however, requires additional context in order to determine whether the destination that the speaker refers to is the speaker's own location at coding time, or a different location.

Verbal deixis may be difficult to acquire from the input, since the choice of the coming/going verb may lack communicative value (VanPatten, 1984) relative to other contextual and lexical cues. Principle P1 of VanPatten's (1996, 2000, 2002) Principles of Input Processing states that "learners process input for meaning before they process it for form" (VanPatten, 2002, p. 758). A correlate of this principle is that "Learners process content words in the input before anything else" (p. 758). These principles suggest that when L2 Spanish speakers can extract the direction of movement through contextual cues, the communicative value of the deictic verb itself will be low. For example, in (16), a previous sentence may have already established that the speaker intended to invite the children to the speaker's residence, in which case the cited ambiguity of direction of movement is resolved absent negotiation of verbal deictics in Spanish. VanPatten $(2002,760)$ argues that "the more a form has communicative value, the more likely it is to get processed and made available in the intake date for acquisition". The low communicative value of deictic verbs therefore suggests that learners are unlikely to extract form-meaning connections from (non-structured) input alone. One important goal of the present study will therefore be the creation of structured input activities that increase the communicative value of deictic verbs while challenging them to analyze the directionality of movement expressed by these verbs. This will encourage learners to process form (verb choice) that may otherwise go unprocessed, thereby making learners notice the different deictic meaning of these verbs.

\section{4. $\quad$ Research Questions}

Q1: What are the relative effects of PI \& MOI on the acquisition of verbal deixis in Spanish involving the verbs ir/venir and llevar/traer on an interpretation task at sentence level?

Q2: What are the relative effects of PI \& MOI on the acquisition of verbal deixis in Spanish involving the verbs ir/venir and llevar/traer on a production task at sentence level?

Q3: Do native speakers of English overgeneralize the use of the verbs venir and traer in contexts that may be more commonly expressed by ir and llevar in Standard Spanish?

\section{Method}

\subsection{Participants and Procedure}

The study consisted of 63 participants from three first-year Spanish courses at a public 
university in Southern California. The control, PI and MOI groups originally consisted of 22, 18, and 23 participants respectively. Ultimately, only the data from 44 students were used in the experiment. The data that was not used in the final study consisted of participants who either failed to attend all three sessions (pre-test, instruction, post-test) or who appeared to make no effort on the task (for example, leaving a large proportion of answers blank). Each student completed a language history questionnaire and data from this questionnaire. From this questionnaire, the following independent variables were generated: sex, age, years of Spanish in high school, regular contact with Spanish speakers (yes/no) and native language.

Each of the three groups performed pre and post-tests, each consisting of an interpretation and a production task. The control group did not receive instruction in the target form. They took a pre-test followed by a post-test fourteen days later. The PI and MOI groups first took a pre-test one week before instruction, then a post-test one week after instruction. Table 1 below, adapted from Benati's (2005, p. 77) study on PI and the English past simple tense, illustrates the steps involved in the study and describes the different treatment groups.

Table 1.

\begin{tabular}{|l|l|}
\hline \multicolumn{2}{|c|}{ PRE-TEST: 1 WEEKS BEFORE INSTRUCTION } \\
\hline PROCESSING INSTRUCTION & MEANING OUTPUT INSTRUCTION \\
\hline - Explicit information about the grammatical feature & - Explicit information about the grammatical feature \\
- Information about processing strategies & - Information about processing strategies \\
- Structured Input Activities & - Meaningful output practice \\
\hline \multicolumn{2}{|r|}{ POST-TEST: 1 WEEK AFTER INSTRUCTION } \\
\hline
\end{tabular}

\subsection{Instructional Materials}

The PI treatment consisted of a packet of materials which included explicit information plus processing strategies (Appendix H \& I) as well as structured input activities (Appendix A). These materials were developed according to Fernández (2008) description of structured input activities. Since PI argues that intake is input-driven (VanPatten, 2002), the PI treatment group did not participate in output activities. All of the activities for the PI group were meaningful, communicative and non-mechanical, and, following Benati (2005), were designed to push Spanish learners to identify and abandon faulty processing strategies.

The MOI treatment also consisted of a package of materials, consisting of explicit information plus processing strategies (Appendix H \& I) as well as meaningful output-based activities (Appendix B).

\subsection{Data Collection}

The research design consisted of a pre-test (Appendix D \& E) in week one, a period of instruction in week two, and a post-test (Appendix F \& G) in week three. The tests each consist of one interpretation and one production task, based on plausible conversations in Spanish between two individuals who are talking over the phone. These tasks resembled the practice activities that students reviewed in each treatment group, though the dialogues were changed. The interpretation task provides students with a dialogue containing deictic verbs, and challenges students to identify the direction of movement associated with each verb. The purpose of this task is to pull students towards noticing the relationship between 
form (the choice of verbs) and identifying whether the deictic verb in question referred to a movement toward or away from the speaker's present location. The production task resembled the interpretation task, except that participants were instructed to fill in the blank with the appropriate verb based on context rather than analyze directionality expressed by the verb.

The data was analyzed using $\mathrm{R}$ Program. A mixed effect model generated individual slopes and intercepts for each participant, thereby controlling for individual variation among test subjects. Model selection was then performed, trimming down the model and determining which of the independent variables actually influenced the outcome.

\section{6. $\quad$ Results \& Discussion}

The dependent variable analyzed in this experiment was a binary categorical variable "RESPONSE" indicating whether the student wrote the correct or incorrect answer based on the verbal deictic system of Spanish described in Shum et ál. (1989) and Lewandowski (2007). For example, in the interpretation task a correct answer for a sentence involving venir would indicate that the movement was directed towards the speaker's location. An example of an answer coded as incorrect in the output task would be, for example, the usage of venir to refer to a movement towards the addressee. The independent variables were time (pre vs. post, coded as 0 and 1 respectively), treatment (control, MOI, or PI), word type (venir, traer, llegar or ir), gender, age, and years of Spanish in high school. An independent variable for native language was ultimately removed from the study, since representation from non-English groups was insufficient. Two-way interactions were considered between all items, with non-significant interactions and main variables eliminated during model selection.

\subsection{Interpretation Task Results \& Discussion}

A mixed effects model was run, generating a varying-intercept group effect for each participant number. The significant main variables and interactions that remained after model selection are shown below:

Table 2. Results of generalized linear mixed model, interpretation task

\begin{tabular}{|l|l|l|}
\hline Estimate & Fixed Effects & P-Value \\
\hline 11.8 & Intercept & $.0048^{*}$ \\
\hline-8.6 & Time (pre or post-test) & $.013^{*}$ \\
\hline-.56 & Age & $.0065^{* *}$ \\
\hline 1.5 & Time: Treatment (MOI) & $.0054^{* *}$ \\
\hline 1.8 & Time: Treatment (PI) & $.00070^{* * *}$ \\
\hline 0.4 & Time: Age & $.0098^{* *}$ \\
\hline
\end{tabular}

The final model eliminated the following variables: verb type, regular contact with Spanish speakers, years of Spanish in high school, and gender. The final model was expressed using treatment contrasts. Treatment contrasts capture the alphabetically first level of each categorical variable. Thus, the intercept is the value generated by our model under the following assumptions: Time $=$ Pretest, Treatment $=$ Control. 
A mixed effects model showed the significant (TIME) and highly significant (AGE, TIME:TREATMENT, TIME:AGE) correlations between the independent variables and students' outcomes on the interpretation task.

There was a significant negative coefficient for the variable TIME $(\mathrm{p}=.013)$, which indicates that holding AGE and TREATMENT constant, students performed more poorly on the post-test (coded as 1 ) than on the pre-test (coded as 0 ). These results suggest that independent of the type of instruction received (none, MOI, or PI), the post-test was significantly more challenging for the students than the pre-test. It may have been the case that the output-based and input-based post-tests were more challenging because, in effect, they represented the second iteration in which the researcher was asked to create a meaningful dialogue between two participants focused entirely around the use of the four verbs in question.

There was a significant positive interaction between both TIME and PI TREATMENT $(\mathrm{p}=.00070)$ and TIME and MOI TREATMENT $(\mathrm{p}=.0054)$, showing that both treatment groups performed significantly better on the interpretation post-test than on the interpretation pre-test, in comparison to the control group. This suggests that both instructional methods resulted in a significant improvement in students' ability to interpret the directionality of movement of deictic verbs in Spanish. On the aggregate, the results suggest that receiving explicit information and performing either input-based or output-based follow-up activities helped students improve their ability to recognize the direction of movement expressed by deictic verbs.

Figure 1 below shows the interaction between the time and treatment variables, illustrating that participation in the treatment groups resulted in a significant gain in performance between pre and post tests.

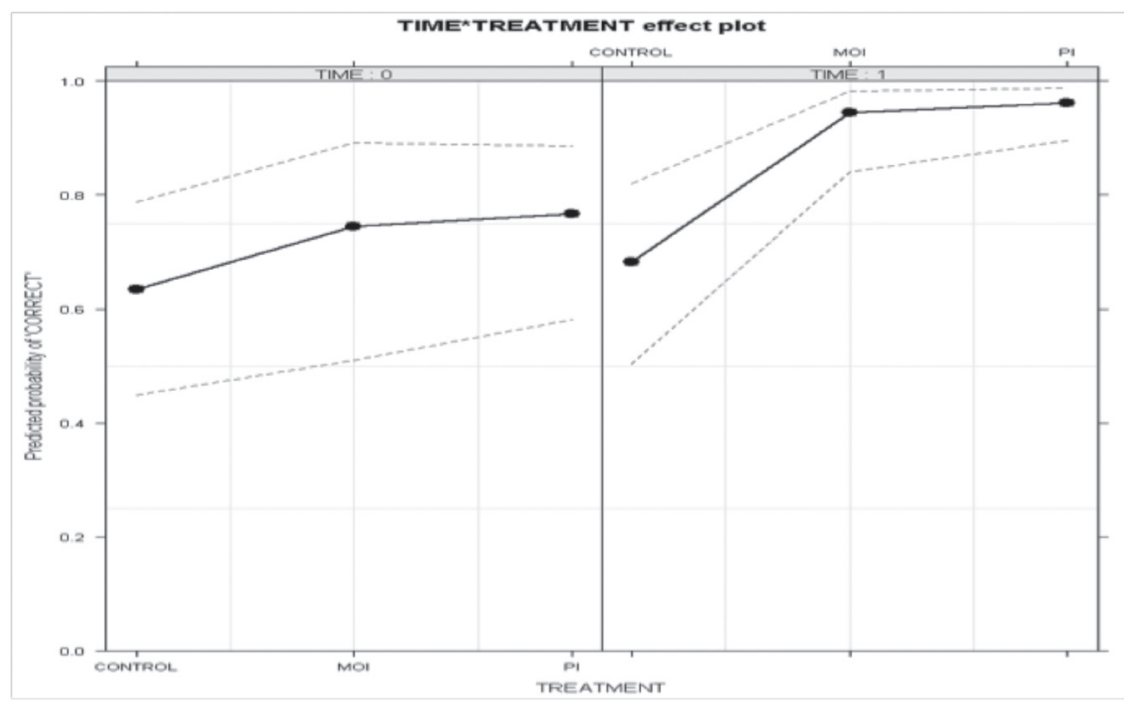

Figure 1. Interaction between time (pre vs. post test) and treatment (PI vs. MOI)

A separate model was run in order to compare solely the MOI vs. PI treatments, excluding the control group. The final model selected when the control group data was excluded contained only one significant independent variable: TIME $(\mathrm{p}<.005)$. In other words, while both MOI and PI treatments were significantly different from the control group in our original model, there was no significant difference in the gains realized by the two treatment groups. Both treatments appeared to be effective methods to teach students to recognize the directionality of movement expressed by 
deictic verbs: thus, it didn't matter whether students performed output-oriented or input-oriented tasks during instruction, both groups performed equally well on the interpretation task.

\subsection{Output Task Results \& Discussion}

A mixed effects model was run, generating a varying-intercept group effect for each participant number. The final model after model selection is shown below:

Table 3. Results of generalized linear mixed model, output task

\begin{tabular}{|l|l|l|}
\hline Estimate & Fixed Effects & P-Value \\
\hline 2.56 & Intercept & .31 \\
\hline 6.70 & Time (pre or post-test) & $.0098^{* *}$ \\
\hline 1.60 & Treatment (MOI) & $.0024^{* *}$ \\
\hline .91 & Treatment (PI) & $.042^{*}$ \\
\hline-1.5 & Type (Llevar) & $.00053^{* * *}$ \\
\hline 2.60 & Type (Traer) & $3.7 e-07^{* * *}$ \\
\hline-2.44 & Treatment (MOI): Type (Traer) & $.00018^{* * *}$ \\
\hline .99 & Time: Type (Llevar) & $.030^{*}$ \\
\hline-1.30 & Time: Type (Traer) & $.013^{*}$ \\
\hline-.32 & Time: Age & $.012^{*}$ \\
\hline
\end{tabular}

The final model eliminated the following variables: regular contact with Spanish speakers, years of Spanish in high school, an interaction between time and treatment, and gender. Unlike in the interpretation task, there were significant main effects and interactions involving verb type.

Again, treatment contrasts capture the alphabetically first level of each categorical variable. Thus, the intercept is the value generated by our model under the following assumptions: Time $=$ Pretest, Treatment $=$ Control, Type $=$ Ir .

A mixed effects model showed the significant (TIME, TIME:TYPE, TIME:AGE) and highly significant (TYPE, TREATMENT:TYPE) correlations between the independent variables and students' outcomes on the output task. There was a significant positive coefficient for the main variable TIME $(\mathrm{p}=.009)$, which indicates that students performed significantly better on the verb IR on the post-test than on the pre-test. These results suggest that some learning took place as a result of participating in the pre-test and post-test, even absent instruction.

There were also significant main effects for the MOI treatment $(\mathrm{p}=.002)$ and for the PI treatment $(\mathrm{p}=.043)$. These results suggest that students in the MOI and PI groups overall outperformed the control group on the output task in both the pre and the post-tests, especially with respect to the verb ir. The MOI and PI groups had higher starting performance on the verb ir than the control group.

The strongest main effects were those of verb types llevar $(\mathrm{p}=.00053)$ and traer $(\mathrm{p}<.0005)$. The verb llevar presented more difficulty to speakers in all three groups, in both the pre-test and post-test. Conversely, students across treatment type and in both pre and post-tests tended 
to perform better on the verb traer. These results suggest that llevar may not be productively present in the systems of students of first-year Spanish, and that traer is present and perhaps overgeneralized to non-prescriptive cases of movement away from the speaker's present location.

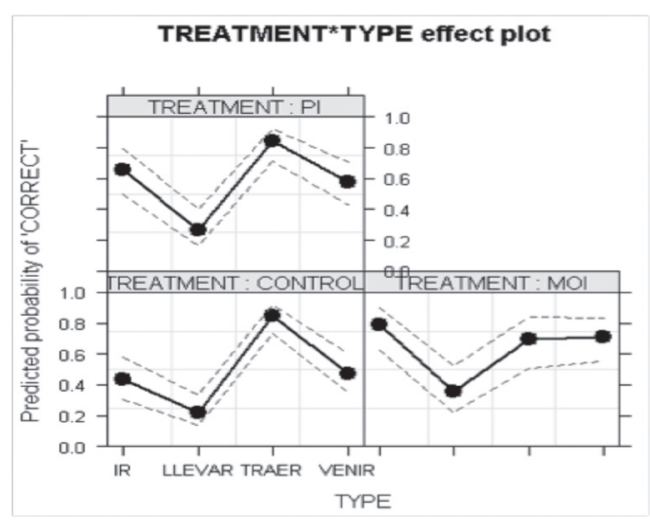

Figure 2. Interaction between treatment (MOI, PI, control) and verb type

The model also revealed a highly significant relationship between the treatment type students received and the verbal type $(\mathrm{p}=.012)$. This relationship is represented graphically below.

The model indicates that the main area of difference between how the different treatment groups responded to the different verb types lies in the nonconforming behavior of the verb traer in the MOI group ( $\mathrm{p}=.00018)$. The MOI group overall performed significantly worse on the verb traer (in both pre and post-tests) than the control and the PI group. The graph also shows the overall trend that the verb llevar presented the greatest difficulties for all groups. It is worth noting that unlike the results for the outcome test, the final model for the interpretation test did not accept verb type as a predictor variable. This suggests that students in first-year Spanish do have some receptive ability of the verb llevar and its usage for expressing movement away from the speaker. However, as mentioned above, this verb may not have been available for productive in the systems of these first-year Spanish students.

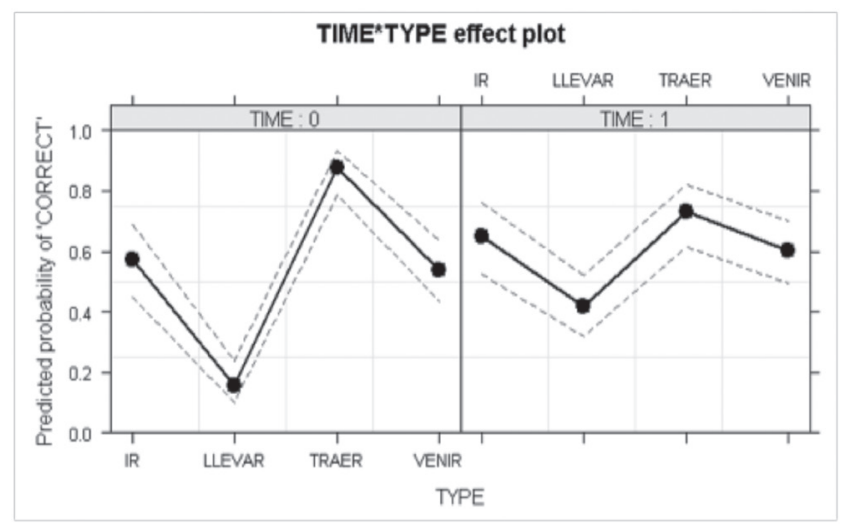

Figure 3. Interaction between time (pre vs. post test) and verb type

The model also captured a significant reaction between time and verb type, shown below. This interaction represents the difference in the predicted probability of choosing the correct answer by verb type, in the control group, during the pre and post-tests. Significant effects 
were observed for interactions between the time variable and the verbs llevar $(\mathrm{p}=.029)$ and traer (.014). This result suggests that holding treatment constant, students who completed the pre-test are able to make significant changes in their knowledge of the verbs llevar and traer. We should not be alarmed that students tended to do slightly worse with the verb traer during the post-test, since the high percentage of correct assessments of this verb on the pre-test is largely due to the blanket overgeneralization of the use of this verb. ${ }^{2}$ Moving from the pre-test to the post-test, we see that students become more willing to recognize that some cases of traer may be better expressed by the verb llevar: while improvement in llevar appears to come at the expense of the verb traer, this can be viewed as evidence that restructuring is taking place in the deictic system of speakers. It is also worth noting that the interaction between time and verb type applies to all of the groups, including the control group. It may have been the case that the control group received incidental input (Morgan-Short \& Bowden, 2006, p. 42) by participating in the interpretation pretest, and that this input alone was sufficient for them to notice that llevar can be used to express what in English is often expressed by the verb "to bring".

The most surprising result of the mixed-effects model for the output task is that the interaction between time and treatment was eliminated during model selection $(\mathrm{p}=.06)$. A closer look at the cause of this marginal significance may be merited. The elimination of the TIME:TREATMENT interaction was largely due to non-improvement by the MOI group between pre and post-test in the output task. The following is a graphical representation of the non-significant interaction between time and treatment variables.

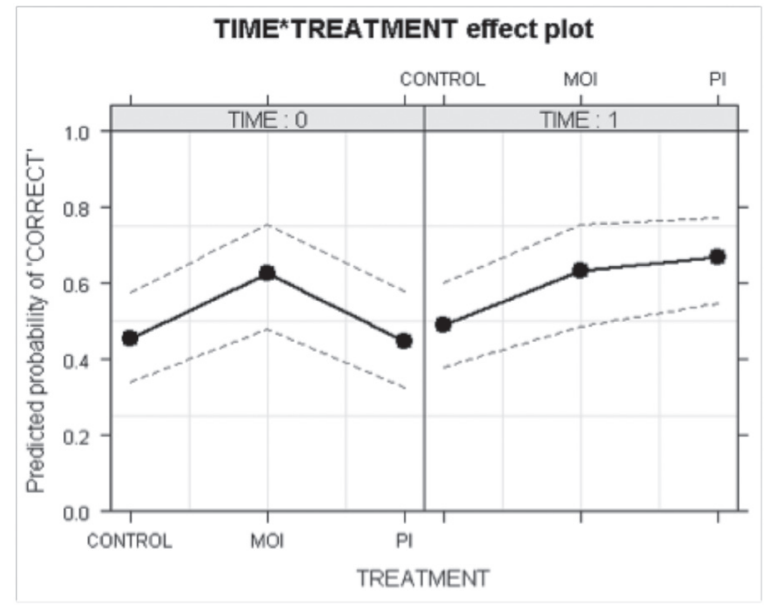

Figure 4.

Figure 4 shows that the MOI group's failure to improve between pre and post tests may be due to ceiling effects: the MOI group already did well on the pre-task, thus it was easier for the PI group to show an improvement between pre and post-test because the PI group had a lower starting point. The wide confidence intervals show that there was considerable variation around the means, another factor that contributed to the marginal significance (and thus elimination) of the TIME:TREATMENT variable in the final model. The decision to eliminate this interaction in the final model yields the following conclusion: neither Processing Instruction nor Meaning-Based Output Instruction helped increase the likelihood of the participants correctly producing the deictic verbs in question. 


\subsection{Output Pre-Test Results}

The present study, in addition to being experimental, is exploratory. Research question 3 asked whether students overgeneralize the use of the verbs venir and traer in contexts involving motion away from the location of the speaker, that is, in contexts where native Spanish speakers tend to favor the verbs ir or llevar respectively. The graph below shows the percentage results of students' choices of the four verb types, across all treatment types. The table shows a percentage, which is calculated by taking the total number of student responses for a given verb and dividing it by the total number of test questions for which the expected answer was that verb. For example, we see that students chose the verb ir 49 times out of the 90 instances in which we expected students to choose the same verb. The intersection between the study's criterion for correct verbal selection and the student response is shown in yellow below.

Table 4. Percentage of correct participant responses per verb type

\begin{tabular}{|l|l|l|l|l|}
\hline & EXPECTED ANSWER & & & \\
\hline STUDENT RESPONSE & IR & LLEVAR & TRAER & VENIR \\
\hline IR & $\mathbf{0 . 5 4}$ & 0.030 & 0.022 & 0.19 \\
\hline LLEVAR & 0.078 & $\mathbf{0 . 1 8}$ & 0.07 & 0.10 \\
\hline TRAER & 0.011 & 0.76 & $\mathbf{0 . 8 6}$ & 0.16 \\
\hline VENIR & 0.37 & 0.022 & 0.056 & $\mathbf{0 . 5 3}$ \\
\hline
\end{tabular}

For the verb ir, students correctly answered with the verb ir 54\% of the time. However, with the same verb students tended to use the verb venir nearly $37 \%$ of the time. Clearly, absent instruction on deictic rules in Spanish, the students' systems show considerable interference from English. The verb llevar shows an even more striking result. Students only correctly produced the verb llevar in $18 \%$ of the cases. In $76 \%$ of cases they used the word traer, suggesting a strong influence from the deictic system of English. As mentioned above, the overuse of the verb traer for the expected verb llevar may also in part be due to a lack of productive knowledge of the verb llevar. If this is the case, students may have chosen traer due to a combination of familiarity with the verb traer over llevar and an over-application of the verbal-deictic rule from English. The participants appeared to face less difficulty in correctly producing the verb traer, producing the correct form $86 \%$ of the time. Finally, the verb venir presented itself as an area of confusion for some students, who incorrectly used the verbs ir (19\%), llevar (10\%), and traer (16\%). Participant responses were not limited to the four deictic verbs, three other responses observed were leaving the answer blank (1), llegar (2) and ser (1). However, these responses were so few that we eliminated them from analysis.

\section{Conclusion}

The following table summarizes the results of the experiment.

Table 5. Overall summary of results

\begin{tabular}{|l|l|l|l|l|}
\hline & $\begin{array}{l}\text { Significant Main } \\
\text { Effects/Direction }\end{array}$ & P-value & $\begin{array}{l}\text { Significant Interactions/ } \\
\text { Direction }\end{array}$ & P-value \\
\hline Interpretation & TIME (-) & $.005(* *)$ & TIME:AGE (+) & $.009(* *)$ \\
Task & AGE (-) & $.006(* *)$ & TIME:TREATMENT (+) & $.0003(* * *)$ \\
\hline
\end{tabular}




\begin{tabular}{|l|l|l|l|l|}
\hline Output Task & TIME $(+)$ & $.0098(*)$ & TYPE (MOI): & $.00018(* * *)$ \\
& TREATMENT MOI $(+)$ & $.0024(* *)$ & TREATMENT (TRAER) $(-)$ & \\
& TREATMENT PI $(+)$ & $.042(*)$ & TIME: TYPE (LLEVAR) $(-)$ & $.030(*)$ \\
& TYPE LLEVAR $(-)$ & $.00053(* * *)$ & TIME:TYPE (TRAER) $(+)$ & $.013(*)$ \\
& TYPE TRAER $(+)$ & $<.0005(* * *)$ & TIME: AGE $(-)$ & $.012(*)$ \\
\hline
\end{tabular}

Research Question 1 asked what effects Processing Instruction and Meaning-Based Output Instruction had on students' performance on an interpretation task at the sentence level. The results showed that both the PI and MOI group showed a significant improvement between the pre and post-tests, relative to the control group. There was no significant difference detected between the improvements realized by the PI and MOI groups. Students were able to demonstrate a significant improvement in their ability to correctly identify the direction of movement of deictic verbs in Spanish, regardless of whether the instruction consisted of output-oriented or input-oriented activities.

Research Question 2 asked what effects Processing Instruction and Meaning-Based Output Instruction had on students' performance on an output task at the sentence level. A marginally significant interaction between TIME and TREATMENT was observed, but ultimately discarded in the final model. The final model suggests that both Processing Instruction and Meaning-Based Output Instruction failed to result in an improvement between pre and post-tests on students ability to produce the correct verb within a meaningful dialogue.

The main effect of TREATMENT suggests that the MOI and PI groups performed significantly better than the control group on a whole, suggesting underlying differences in the groups surveyed rather than the effectiveness of the treatments. The main effect of TYPE shows that llevar was difficult for students, while traer appeared to be well-understood. The interaction between TYPE and TIME suggests that all three groups improved on their performance in the verb llevar between pre and post-tests, at the expense of the verb traer. The improvement of even the control group on the verb llevar suggests that students may have benefited from incidental input received solely by participating in the interpretation task. It is possible that the decreased performance on the verb traer indicates a period of restructuring in the verbal-deictic interlanguage of the participants, in which students learn that they cannot always trust their English-speaking intuition with regards to the verbs traer and venir.

Finally, research question 3 asked whether students' responses prior to instruction suggested the application of verbal-deictic rules from English in their interlanguage. An analysis of the pre-test results of the output task show that participants used the verb venir $37 \%$ of the time when ir was expected, and traer $76 \%$ of the time when llevar was expected.

Future studies should include measures to determine whether students are able to interpret and produce the meaning of the different verbs in question. For example, prior to completing the pre-test, students might be asked to write an English translation of the verbs llevar, venir, ir and traer. In this way, we would be able to determine whether the apparent overuse of traer for prescriptive llevar was due to a lack of knowledge of the verb llevar or due to an application of verbal-deictic rules of English in the interlanguage. The marginally significant interaction between TIME and TREATMENT that was discarded in the final model suggests that more studies should be done, so as to rule out the role of ceiling effects that were observed in the MOI group which ultimately contributed to the non-significance of 
the interaction. For example, it may be the case that regardless of whether students received MOI or PI, students who were past a certain threshold were able to improve on the structure and students who were not past this threshold were not. In addition, future studies may reduce the processing load in the output task by simply asking students to place the infinitive form of the verb in question, without being concerned with conjugation. In the present project, students were asked to conjugate the verbs but in the end the data was coded with respect to the infinitive of the verb they tried to conjugate: thus even incorrect conjugations within the desired verb would have been considered correct answers. Finally, future studies would benefit from more explicitly telling students that the dialogue that they are being asked to analyze are taking place over the phone: the dialogues often involved invitations to move towards the present location of the person who was speaking, or offers to bring something from the speaker's location to the hearer's. These dialogues would only be logical if the interlocutors are at a different physical location, and thus this aspect should be more clearly explained in the materials and instruction.

Ultimately, the results suggest that students in their third quarter of first-year Spanish are developmentally prepared to benefit from instruction on the verbs venir, ir, traer and llevar with regards to interpreting input. However, they do not appear to be developmentally ready to apply this instruction to the actual production of these verbs. It is the researcher's hope that helping students increase their receptive knowledge of verbal deixis in Spanish will promote noticing (Schmidt, 1993) of the structure in the future. Until then, it appears that at least some learners of L2 Spanish will continue insisting on coming to the party.

\section{Notes}

1. An asterisk was only included in the English gloss if it would be unacceptable in English in the given sentence. If the use of a given deictic verb would be acceptable in English, no asterisk is included.

2. In the scoring of correctness in this experiment, answers were considered correct or incorrect within their verb type: thus, if a student answered traer when the expected answer was llevar, the error would have been coded under the verb llevar. Thus, if a student only used the word traer in all cases for which either traer and llevar would have been appropriate, they would have scored $100 \%$ on the traer verb (and subsequently $0 \%$ on llevar).

\section{Bibliography}

Benati, A. (2005). The effects of processing instruction, traditional instruction and meaningoutput instruction on the acquisition of the English past simple tense. Language Teaching Research. 9 (1), 67-93.

Cheng, A. C. (2002). The effects of processing instruction on the acquisition of ser and estar. Hispania. 85 (2), 308-323.

Collentine, J. (1998). Processing instruction and the subjunctive. Hispania. 81 (3), 576-587.

Collentine, J. (2010). The acquisition and teaching of the Spanish subjunctive: An update on current findings. Hispania. 93 (1), 39-51.

Farley, A. P. (2001a). Authentic processing instruction and the Spanish subjunctive. Hispania. 84 (2), 289-299. 
Farley, A. P. (2001b). The effects of processing instruction and meaning-based output instruction. Spanish Applied Linguistics. 5 (1), 57-94.

Fernández, C. (2008). Reexamining the role of explicit information in processing instruction. Studies in Second Language Acquisition. 30 (03), 277-305.

Fillmore, C. J. (1975). Santa Cruz Lectures on Deixis 1971.

Gathercole, V. C. (1978). Towards a universal for deictic verbs of motion. Kansas Working Papers in Linguistics. 3, 72-88.

Lewandowski, W. (2007). Toward a comparative analysis of coming and going verbs in Spanish, German, and Polish. (Master's thesis). Universitat Autònoma de Barcelona.

Morgan-Short, K., \& Bowden, H. W. (2006). Processing Instruction and Meaning-Based Output Instruction: Effects on Second Language Development. Studies in Second Language Acquisition. 28 (01), 31-65.

Schmidt, R. (1993). Awareness and second language acquisition. Annual review of applied linguistics. 13 (1), 206-226.

Shum, G., Conde, A., \& Díaz, C. (1989). ¿Cómo se adquieren y usan los términos deícticos en lengua española? Un estudio longitudinal. Infancia y Aprendizaje. 48, 45-64.

VanPatten, B. (1984). Communicative values and information processing in L2 acquisition. ERIC Clearinghouse.

VanPatten, B. (1996). Input processing and grammar instruction in second language acquisition. Greenwood Publishing Group.

VanPatten, B. (2000). Thirty years of input (or intake, the neglected sibling). In B. Swierzbin, F. Morris, M.E. nderson, C.A. Klee \& E.Tarone (Eds.) Social and cognitive factors in second language acquisition: Selected Proceedings of the 1999 Second Language Research Forum. Somerville. (287-311). MA: Cascadilla.

VanPatten, B. (2002). Processing instruction: An update. Language learning. 52 (4), 755-803.

VanPatten, B., \& Cadierno, T. (1993). Explicit instruction and input processing. Studies in second language acquisition. 15 (02), 225-243. 


\section{APPENDIX A: Processing Instruction}

\section{Activity 1 (Referential structured input):}

Below, you will read 10 sentences with the verbs llevar, ir, traer, and venir. You must determine whether the movement described by the verbs is directed towards the speaker's present location or away from the speaker's present location. If you do not know the answer, mark "Don't know".

You will receive feedback upon completion of the activity. If your answer was incorrect, place an $\mathrm{X}$ next to the question.

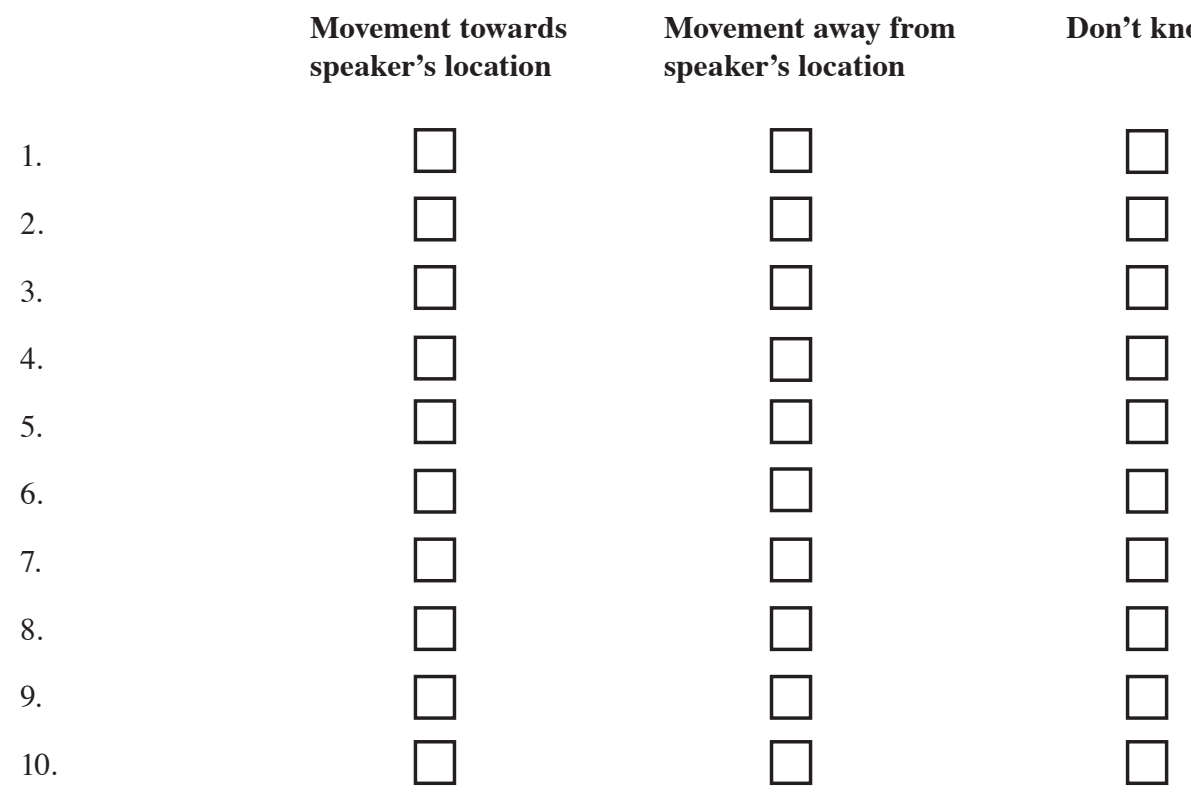

1. María: Juan, tengo una fiesta el sábado. ¿Quieres venir?

2. Juan: Claro que sí. Me encantaría ir.

3. María: Si no te importa, podrías traer unos refrescos?

4. Juan: Por supuesto. Te los llevo.

5. María: Por cierto, ¿no me dijiste que me ibas a presentar a tu hermanito? ¿Lo vas a traer?

6. Juan: Claro. Después de comprar los refrescos, voy por él (I’ll pick him up) y juntos vamos a tu fiesta.

7. María: ¡Chévere! Tengo muchas ganas de conocerlo. ¡Ah! Una última cosa, parece que va a llover (rain). No te olvides de traer un paraguas (umbrella).

8. Juan: Tienes razón. Será mejor llevarlo por si llueve (in case of rain).

9. Juan: Es posible que yo llegue un poco tarde. Mi padre quiere que vaya a su casa para ayudarle con algo.

10. María: No pasa nada (it's okay), pero si vienes muy tarde ya no tendrás para comer! 


\section{Activity 2 (Structured Input)}

You will be shown a series of drawings, depicting motion. The drawings that contain a picture of a wrapped present indicate a choice between llevar or traer. The drawings that do not have a wrapped present indicate a choice between ir and venir. You must decide whether the action being shown would best be described by the verbs ir, venir, llevar or traer. Check the box that best describes the action.

Ir

Venir

Traer

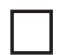

1.
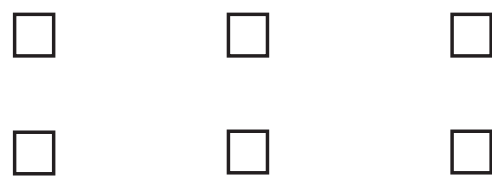

3.

4.
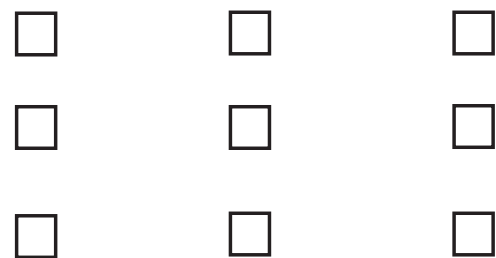

Llevar

Don't know

1.1

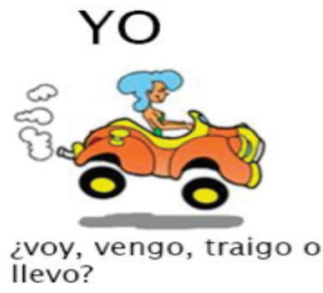

la fiesta de mi amiga

2.
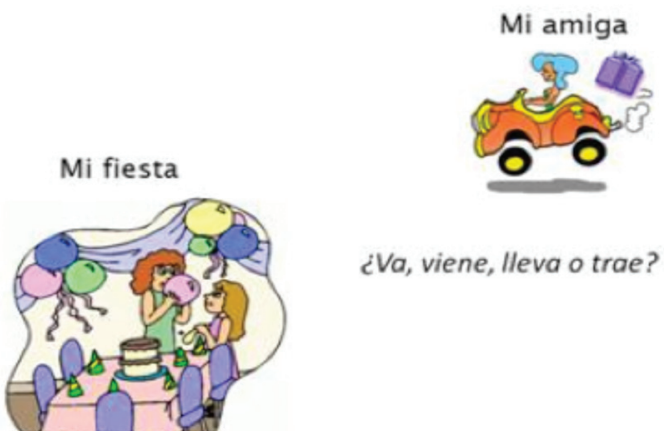

¿Va, viene, lleva o trae?

1 Images' source: prepared by the author. 
3.

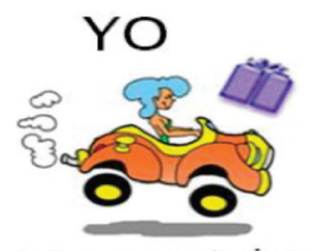

la fiesta de mi amiga

¿voy, vengo, traigo o llevo?

4.

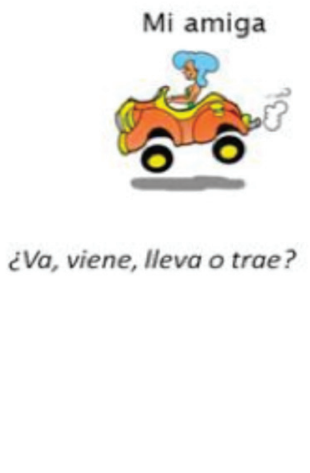

\section{APPENDIX B: Meaning Based Output Instruction}

\section{Activity 1 (Meaningful Output Activity)}

Decide which verb from the following list is appropriate given the context. Conjugate the verb if necessary. You will receive feedback upon completion. If your answer was incorrect, place an $\mathrm{X}$ next to it.

\section{TRAER}

IR

VENIR

\section{LLEVAR}

1. María: Juan, tengo una fiesta el sábado. ¿Quieres $?$

2. Juan: Claro que sí. Me encantaría

3. María: Si no te importa, podrías unos refrescos?

4. Juan: Por supuesto. Te los

5. María: Por cierto, ¿no me dijiste que me ibas a presentar a tu hermanito? ¿Lo vas a ?

6. Juan: Claro. Después de comprar los refrescos, voy por él (I'll pick him up) y juntos a tu fiesta.

7. María: ¡Chévere! Tengo muchas ganas de conocerlo. ¡Ah! Una última cosa, parece que va a llover (rain). No te olvides de un paraguas (umbrella).

8. Juan: Tienes razón. Será mejor lo por si llueve (in case of rain).

9. Juan: Es posible que yo llegue un poco tarde. Mi padre quiere que a su casa para ayudarle con algo.

10. María: No pasa nada (it's okay), pero si muy tarde ya no tendrás para comer! 


\section{Activity 2 (Meaningful Oral Production)}

In this oral signature activity, half of the students will take the role of a party host and the other half will be guests. The hosts are contacting the guests by phone.

STEP 1: The hosts will A) ask guests to bring food items to the party and B) confirm at what time they plan on coming. The host and guest may consult the following list of food items. STEP 2: The host will gather the signature of the attendee and note at what time they will arrive and what food item they will bring. The attendee responds to the host's questions.

The goal of the activity is to practice the verbs ir/venir and traer/llevar.

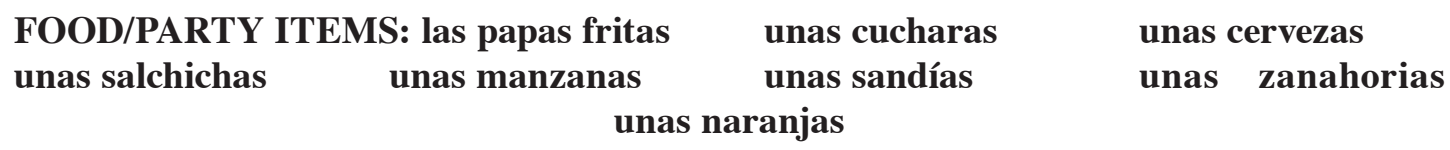

EJ:Estudiante 1: Podrías (TRAER o LLEVAR) (COSA) a mi fiesta el sábado? (TRAERLAS o LLEVARLAS).

Estudiante 2: Claro que sí. Puedo (VENIR O IR)

Estudiante 1: $\mathrm{Y}$ a qué hora piensas (HORA) de la noche.

Estudiante 2: Voy a (VENIR o IR) a las

\section{APPENDIX C: Output-Based Pre-Test}

Decide which verb from the following list is appropriate given the context. Conjugate the verb if necessary.

\section{$\begin{array}{llll}\text { TRAER } & \text { IR } & \text { VENIR } & \text { LLEVAR }\end{array}$}

Julio: Dani, hombre, ¿cuándo vas a 1) a mi casa para ver mi nueva HDTV?

Daniel: Pues quiero, pero esta mañana estoy super ocupado porque tengo que 2) a mi hermanito a la escuela. ¿Podría 3) a tu casa después?

Julio: Vale, me parece muy bien. ¡Ah! Casi se me olvida, necesito un cable HDMI para la HDTV. ¿Podrías 4) uno?

Daniel: Sí creo que tengo uno en casa. Te lo puedo 5) cuando 6) a tu casa.

Julio: Perfecto. También va a 7) mi amigo Ignacio. Creo que no lo conoces.

Daniel: Claro que lo conozco. ¿No te acuerdas (you don't remember)? Él 8) a mi fiesta de cumpleaños el año pasado. Es muy gracioso.

Julio: Sí lo es. Él me dijo que iba a 9) su consola Playstation 3.

Daniel: ¡Genial! ¿Quieres que yo 10) mi X-Box?

Julio: Me parece una idea estupenda. Nos vemos en un par de horas. 


\section{APPENDIX D: Interpretation Pre-Test}

Below, you will read 10 sentences with the verbs llevar, ir, traer, and venir. You must determine whether the movement described by the verbs is directed towards the speaker's present location or away from the speaker's present location.

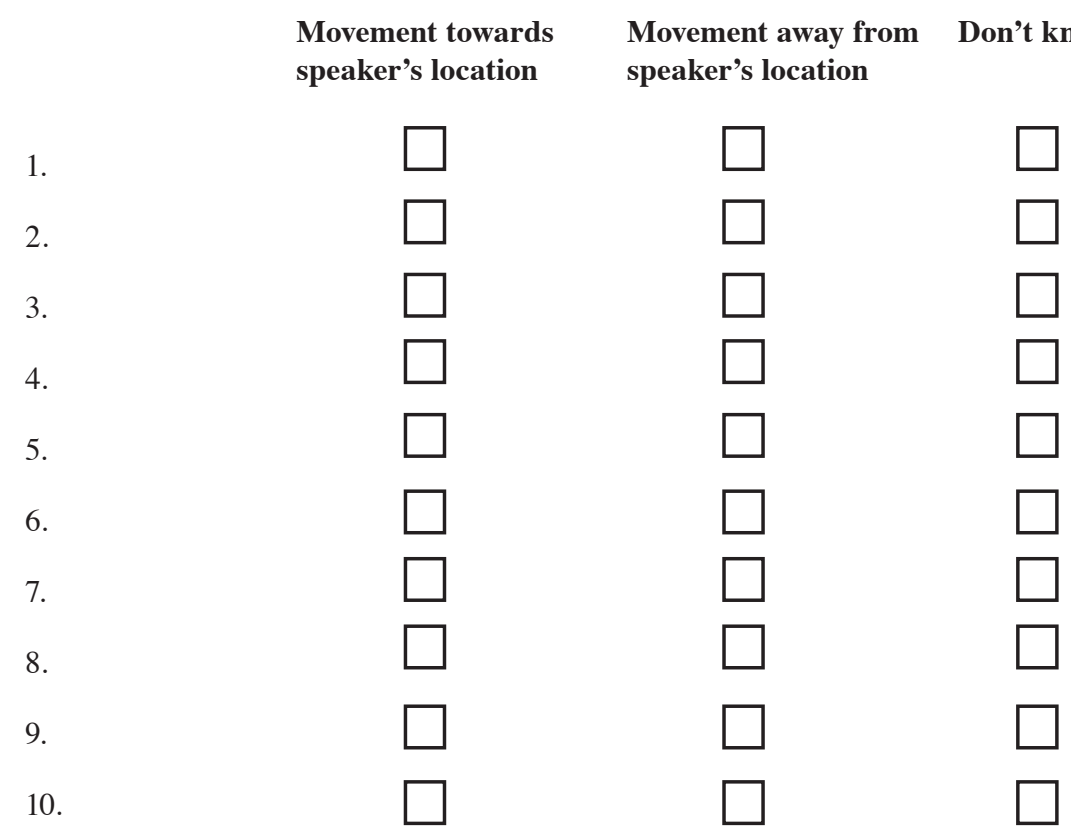

1. David: ¡Hola Wendy! Estamos teniendo un picnic en el parque cerca de mi casa. ¿Quieres venir?

2. Wendy: Lo siento, estoy en casa un poco enferma y no puedo ir.

3. David: Pobrecita. ¡Te voy a llevar una sopa de pollo y así te sentirás mejor!

4. Wendy: No no, no te preocupes. Estoy con mi novio y él me está cuidando. No tienes que traerme nada. ¡Pero gracias!

5. David: Quizás (maybe) después del picnic, todos podemos ir a tu casa para visitarte. ¿Qué te parece (how does that sound)?

6. Wendy: Prefiero que no venga nadie a visitarme.. lo siento, pero no estoy en condiciones de recibir a invitados.

7. David: Vale, te entiendo. Por cierto (by the way), ¿vas a ir al concierto de música jazz este fin de semana?

8. Wendy: Si me siento mejor, entonces sí pienso que voy a ir.

9. David: Genial. Quizás nos vemos allí. Voy a llevar a mi hermanito al concierto. A él le encanta la música jazz.

10. Wendy: ¡Estupendo! Una última cosa, es posible que llueva este fin de semana. Si vas al concierto, no te olvides de llevar un paraguas (umbrella). 


\section{APPENDIX E: Output-Based Post-Test}

Decide which verb from the following list is appropriate given the context. Conjugate the verb if necessary.
TRAER
IR
VENIR
LLEVAR

Carolina: ¡Pilar! Este fin de semana espero, por fin, visitar tu nueva casa. ¿Puedo 1) el sábado?

Pilar: El sábado voy a estar fuera. ¿Podrías 2) el domingo?

Carolina: Vale, te visito el sábado a mediodía. Voy a 3) un buen vino para celebrar.

Pilar: Caro, ya sabes que no hace falta (it's not necessary) 4) nada.

Carolina: ¿En serio piensas que voy a 5) a tu nueva casa sin ningún regalito?

Pilar: Vale, Carolina. Si me quieres regalar un vinito está bien. Pero la próxima vez que yo te visite me toca a mí (it's my turn to) 6) una botella.

Carolina: Muy bien. Por cierto, Sara me mencionó que ella también quiere ver tu nueva casa. ¿Puede 7) ella?

Pilar: Por supuesto, Sara me cae muy bien. Pero espero que no 8) a su novio. Aquel tipo es muy molesto (annoying).

Carolina: Si 9) a su novio, ¡yo no voy tampoco (either)!

Pilar: Jajaja. Bueno, nos vemos el sábado entonces. No comas antes. Quiero que 10) con hambre porque voy a preparar un almuerzo muy sabroso

\section{APPENDIX F: Interpretation Post-Test}

Below, you will read 10 sentences with the verbs llevar, ir, traer, and venir. You must determine whether the movement described by the verbs is directed towards the speaker's present location or away from the speaker's present location. If you do not know the answer, mark "Don't know".

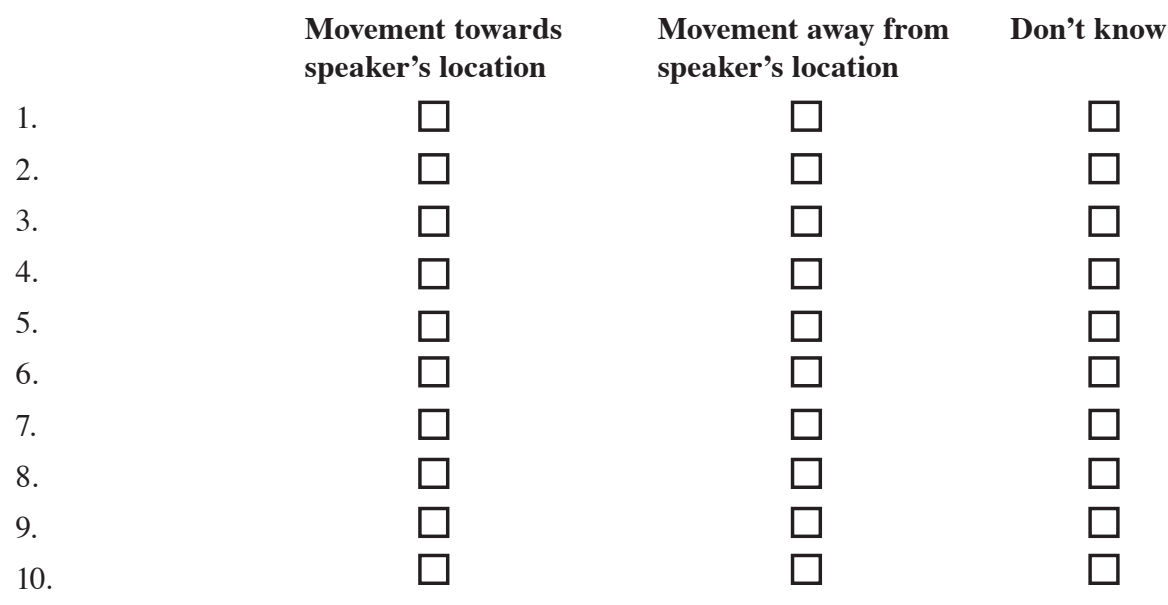


1. Laura: Este sábado voy a tener una comida comunitaria (potluck) aquí en mi casa. Cada invitado va a traer un plato.

2. Eduardo: Hmm.. estoy pensando en qué voy a llevar.

3. Laura: ¿Por qué no traes la lasaña que sabes preparar? La última vez que la preparaste, estuvo muy sabrosa.

4. Eduardo: ¡Qué buena idea! ¿Podrías decirme quién más va a ir? Es que (it’s just that) no tengo coche.

5. Laura: Ya hablé con Sara y con Juan y me dijeron que iban a venir.

6. Eduardo: Perfecto. A lo mejor (maybe) ellos me pueden llevar a la fiesta.

7. Laura: Estoy seguro que sí. Me dijeron que iban a traer a toda la familia, hasta a su perro Antonio.

8. Eduardo: ¿Y qué platos van a llevar ellos a la comida comunitaria?

9. Laura: Sara me dijo que iban a traer un gazpacho. ¡Estoy con ganas de probarlo!

10. Eduardo: ¡Qué emoción! Bueno, me tengo que ir. Hablaré con Sara y Juan para ver si puedo ir con ellos.

\section{APPENDIX G: Explicit Information for PI \& MOI, provided during instruction}

In English, the verbs to come and to bring can be used to express movement away from the speaker.

I'm definitely coming to your party.

I'll bring chips and salsa.
DESTINATION: friend's party

DESTINATION: friend's party

However, Spanish forbids the use of equivalent verbs venir 'to come' and traer 'to bring' to express movement away from the speaker. Instead, Spanish uses a separate set of verbs to capture movement away from the speaker: ir 'to go' and llevar 'to take'.

Claro que renge VOY a tu fiesta.

Traigo LLEVARÉ tostadas y salsa.
DESTINATION: friend's party

DESTINATION: friend's party

\section{APPENDIX I: Additional warning on faulty processing strategy in PI \& MOI}

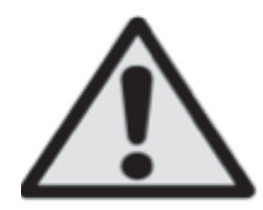

English speakers are likely to draw upon their native intuition to convey movement of persons and objects, wrongly using venir and traer to represent movement away from the speaker's location. In Spanish, you cannot "come/venir" from a place where you currently are to another place. Similarly, you cannot "bring/traer" an item from a place where you currently are to another place.

Spanish-language learners must carefully assess whether movement is occurring towards or away from the location of the person who is speaking. If the movement occurs towards the speakers location, venir and traer are appropriate choices, as below: 
(1) Quiero que vengas a mi casa

DESTINATION: speaker's location I want you to come to my house

(2) Quiero que traigas unos regalos DESTINATION: speaker's location I want you to bring some gifts

However, if the movement occurs away from the speaker's location, ir and llevar must be used. Notice that the English translation of the above sentences prefers the coming and bringing verbs:

(3) ¿Quieres que (yo) vaya a tu casa?

DESTINATION: friend's house

Do you want me to come to your house?

(4) ¿Quieres que lleve algún regalo?

DESTINATION: friend's house

Do you want me to bring a gift?

This faulty processing strategies can lead to ungrammatical usages of the verbs venir and traer, as indicated by the crossed-out text and asterisk below:

(5) ¿Quieres que (yo) venga* vaya a tu casa?

(6) ¿Quieres que traiga* lleve algún regalo?

English speakers should be aware that the relative permissiveness of the coming/going and bringing/taking verbs in English may make it difficult for them to extract the rule stated above from the Spanish language materials they are exposed to. Since Spanish has a more restrictive system than English, English speakers do permit usages of to go and to take that resemble those in (3) and (4). The problem is that these usages compete with more preferred verbal choices in English, namely to come and to bring. 
